\title{
Religious-Based Environmental Movement Against Corporation in Water Resources Conflict in Pandeglang - Banten, Indonesia
}

\author{
Abdul Hamid ${ }^{1}$, Ika Arinia Indriyany ${ }^{2}$, M. Dian Hikmawan ${ }^{3}$ \\ \{abdul.hamid@untirta.ac.id ${ }^{1}$ \} \\ Universitas Sultan Ageng Tirtayasa ${ }^{1,2,3}$
}

\begin{abstract}
Natural resource conflicts between corporations and local communities were quite common in Indonesia. In an area in Pandeglang-Banten, a giant corporation tried to control the natural resources, especially water. Yet, local communities fought against the corporation's agenda. This paper describes the formation of a religious-based community doing social movement against a big corporation. The research method uses qualitative with case study strategy. The research location was in Cadasari District, Pandeglang Regent, Banten Province, Indonesia. Here, the Muslim community fought against PT. Mayora Indah which try to control water resources. The resistances were led directly by the religious local leaders (Kyai) from local Islamic schools (Pesantren). This paper shows that the pesantren succeeded to make political agenda as well as build community resistances through religious doctrine easily understood by local people to defend their access to water resources.
\end{abstract}

Keywords: Corporations, Kyai, Pesantren, Social Movement, Water Resources Conflict

\section{Introduction}

Conflicts over natural resources were quite common in Indonesia, i.e. government Vs. community; community Vs. community; community Vs. private sector. Frequently, triggers of the conflict were Indonesia's natural wealth which being exploited by big corporations. As a consequences, products of mining, sea, or river suffered damage and loss the quality. Conflicts because of over-exploitation in recent years occurred in various areas such as Kendeng (Central Java), Sukamulya (Tangerang - Banten), KulonProgo (DIY), and Mesuji (Lampung).

In current Banten, the issues of corporate controlling the natural resources became contentious. One issue was what happened in the area of Lontar Island, Serang. The sand on the island of Lontar district, Serang regency, were dredged and used for reclamation in Jakarta. But community around the area were hardly resistant. The dredging finally stopped because Jakarta terminated the reclamation, not because of the local community's movement.

However in Cadasari, Pandeglang-Banten, the community expressed the resistance toward a bottled-water factory trying to exploit the water resources. The locals were against drinking water plant owned by PT. TirtaFresindo Jaya. Hence, the resistance emerged the form of a religious-based social movement. 
Tarrow [1] defines social movements as political resistance that occurs when ordinary people join community groups that more influential in mobilize to fight the power elite, authorities and other opponent parties. It is also stated by Tilly [1], which defines social movements as a continuing gradually action by making collective demands of the other party.

Sztompka in NanangMartono [2], imposes limits the definition of a social movement. According to him, social movements must have four criteria, namely: first, the collectivity; second, have the shared goal, which is to realize certain changes in their society participation defined in the same way; Third, the collectivity relatively scattered but lesser than the formal organization. Fourth, its actions have a high degree of spontaneity but are not institutionalized and unconventional shape.

The collective action is an element that is quite important for the formation of a social movement. Because collective action will be formed when the individuals with full consciousness and rationality want to get involved to act on behalf of collective goods. Thus, the beginning of the formation of social movements will be dominated by community awareness who have organized and autonomous individuals unite into movemnent.

The environmental movement itself is within the category of new social movements. New social movements see other logic underlying someone act collectively. The old social movement assumes that people want to do collective action based on economic factors. New social movement see that people are willing to act may be not due to economic factors but could be the basis of ideological, political, cultural or other identity sources that are used as roots movement. On the basis of this ideology the neighborhood-based social movements can be included as a new social movement [3].

Fig 1. Conflict Fuse PT. Mayora (Laclau\&Mouffe [3])
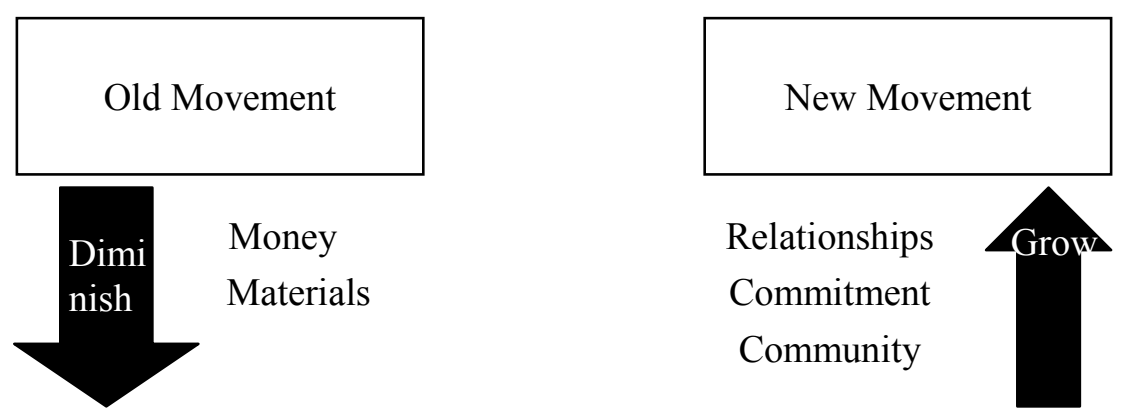

Garner in Suharko [4] describes the development of the environmental movement into three categories: First, a group concerned with the preservation of the countryside as a wonderful place to escape from all the fatigue for the people living in the urban-industrial areas. Second, a group that cares for nature conservation with scientific reasons. Third, the groups are specifically interested in efforts to protect certain animals.

The green movement (environment) expanded rapidly in the 1950s were marked by a number of members grew, and the widespread public concern. There are two main characteristics: appears in the form of mass movement and highlighting the interdependence between environmental problems than the single issue of air-movement.

This movement corresponds to the increasingly acute environmental crisis. There are two phases in the environmental crisis. The first is the first crisis, which triggered by the book 
Rachel Carson: Silent Spring, in the form of a critique of the impact of pesticide use, and large-scale production. Its main focus is the partial environmental degradation such as pollution of river water, or impact on health.

The second phase, the environmental crisis that neither root nor cause a phenomenon of global scale. According to Homer and Dixon in Suharko [4] there are six sources of causes of the global environmental crisis: climate change caused by the greenhouse effect, ozone layer depletion, degradation and loss of fertile agricultural land, degradation and deforestation, reduction and supkai water and the depletion of fishing grounds. Sixth sources such environmental changes, coupled with population growth and uneven distribution of resources, has led to what is known as environmental scarcity.

Actor or agent of the green movement according to Parkin [4] can be divided into four categories: (1) Those who give practical examples of how to implement a lifestyle "green", which includes the organic farmers, who developed the technology alternative , and others. (2) single-issue pressure groups (3) those who work with the example and propaganda in the existing establishment, such as political parties, churches, universities, and others. (4) are distinctive: a green political party (green party).

Model environmental movement are in a continuum between the model reformer (shallow ecology-oriented view-anthropocentrism) and radical models (oriented view of ecology in eco-centrism). Refer to Heijden [5], the environmental movement split into three models: (1) instrumental movement close to the reformist movement models, (2) a counter-cultural movement that is close to the model of the radical movement, and in the center of it there is a sub-cultural movement.

Instrumental movement is divided into three social movements: (1) Conservationists, a movement that has a major concern in the protection of nature or a specific natural area. (2) The policy campaigners, a movement that tried to influence environmental policy makers. (3) The mobilizers, a movement whose main activity drive the public in an environmental action either to the authorities or businesses that decision or behavior is harmful to the environment.

Banten is a western area of Java Island. In general, the region is a former Banten sultanate known as the religious community. More specifically, Pandeglang district which is located on the western tip of Java island is known as the City of Santri (Pesantren Students). As a city of Santri, in Pandeglang there are many Pesantren (Islamic boarding schools) that form the patterned shades of Islamic culture and steeped in religious values with the majority religion of Islam.

As with other regions in Banten, in Pandeglang, Islamic scholars or Kiai has a position as a charismatic leader. Kiai's position as the elite can be explained by the concept of charismatic authority of Max Weber. Refer to Budiardjo [6] charismatic authority is authorized by the trust of community members to the magic and the mystical or religious leader. It could be said that Kiai is the person who acquire religious legitimacy through the expertise and knowledge of its religion.

In the context of Banten this is reflected in the history of Banten sultanate government that is led by the sultans were also Kiai. SyarifHidayatullah (SunanGunungJati) which established the Sultanate of Banten was known as a teacher of Islam, a major pillar of the spread of Islam in Banten. He and his son, Maulana Hasanuddin were religious scholars actively spread Islam. After the Banten Sultanate was abolished in Daendels period, the state became chaotic and the entire social order almost collapsed. In this situation, the leaders emerged from among kiai and other rural elite [7].

In connection with kiai role in political and social life, there are at least three expert opinion. First, the results Geertz research in Java, which concluded that the kiai has a role as a 
cultural broker (broker culture). In the period after independence, there has been a change in the role of kiai, of a communicator which connects the Islamic world based in Mecca with farmers in rural Java, changed the role of a politician who is an agent of the central government in the village.

The Kiai, because of his position, plays a brokerage role for muslims to give them an understanding of what is going on at the national level [8].

Second, Horikoshi`s research in Garut, West Java see that kiai not only did his role as a broker, but Kiai also had the role of social change with its creativity. Kiai was not only drowned as a result of social changes but pioneered social change itself. He did not only filter information, but rather to offer an agenda that considers changes in accordance with the needs of society he leads [9].

This is a refutation of Geertz opinion that as a Cultural Broker Kiai only serves as a link between the modern state with a traditional society where the broker selection where only culture that can be accepted and which should be rejected as if to imply that the cultural broker does not have views and original approaches. [10]

Following the political changes in contemporary post-reform, Kuntowijoyo [11], argued that the Kiai was in a position as a political broker. Although not based on in-depth research as Geertz and Horikoshi, but Kuntowijoyo opinion was based on the role of scholars who conduct political activities by making authority in the field of religion and its followers as a political commodity in the era of liberal politics.

One of the most prominent Kiai in Banten was AbuyaDimyati (1930-2003). In his lifetime, he did not only teach the Santri (Pesantren`s pupils), but also provided a weekly teaching for religious leaders of pesantren kiai entire Banten. The books he teached is difficult and hard enough to be understood as IhyaUlumuddin and Al-Mustasyfa are both written by Al Ghazali. AbuyaDimyati is also MursyidtarikatSyadziliyyah in Indonesia. He was trusted by the students and the community have wisdom and superiority.

In the New Order era, AbuyaDimyati was arrested and imprisoned during the general elections of 1977, because of his statements, that considered attacking the government and Ruling Party - Golkar. On Friday, March 11th, 1977, before Friday prayer AbuyaDimyati said to local village head, so that people should not be frightened and intimidated by the interests of one of the contestants election, with a variety of threats, one of them with the statement that " Golkar is Government", AbuyaDimyati revealed that "the Government is Republic of Indonesia and not Golkar" [12].

One of the sons of AbuyaDimyati who continue charismatic leadership was AbuyaMuhtadiDimyati. In the present time, AbuyaMuhtadiDimyati lead pesantrenCidahu and inherited the important position not only in religious studies, but also in socio-political dynamics in Banten. PesantrenCidahu located in District Cadasari which has environmental problems due to the influx of investment from PT TirtaFresindo Jaya who want to make a bottled water plant which is of course potentially dominate and damage the springs in the area. Around Cidahu there are dozens of other pesantrens where pupils (santri) studying islam religion.

\section{Method}

This study is a qualitative case study type. For qualitative research, this study sought to explore and understand the meaning by individuals or group of people ascribed social or humanitarian issues [13]. 
The research strategy or the type of research is a case study. Qualitative research is a case study research strategy where researchers investigate carefully a program, event, activity, process, or group of individuals. The cases are limited by time and activity, and researchers collected detailed information using a variety of data collection procedures based on a predetermined time [13].

In gathering the data, Researchers use to study documents and interviews. Documents collected are a note describing various community resistance to corporate events, both formal document, informal, and the news media. Studies carried out to establish the construction documents and be a material event for the second method, namely the interview.

In-depth interviews will be carried out against those involved in the two incidents were investigated. Selection of informants is purposive and snowball, especially to: religious leaders, community leaders, corporate parties, people involved in the action, government officials and security forces. The informant who had been interviewed in this study were: (1) Journalists; (2) Kiai (3) Community leaders; (4) The general public; (5) Pupils (6) Jawara.

\section{Result and Discussion}

PT TirtaFresindo Jaya is one of the subsidiaries of PT Mayora that imparts water business investments in Pandeglang - Banten. PT Mayora itself began doing business in Indonesia since 1977, through Coconut Confectionery products Rome. Not only biscuits, developing Mayora Business expansion into confectionery Kopiko, Wafer Beng - Beng, Chocolate Choki - Choki, Coffee Sachet Torabika, Mi Glass, Cereal Energen, Kopiko 78, Tea Shoots Harum, Le Minerale, etc. The amount of PT Mayora reflected in the company's assets reached Rp 12,922 billion as of December 31, 2016.

Expansion PT Mayora to the field of beverage began in 2011, with bottled water marketed Le Minerale through PT TirtaFresindo Jaya. PT TirtaFresindo Jaya is a subsidiary of PT Mayora which is focused on business lines Le Minerale water. Bottled water factory is spread from Cianjur, Palembang, Ciawi, Sukabumi, Pasuruan, Medan and Makassar. In 2014, PT TirtaFresindo Jaya planned to invest in the water business Pandeglang - Banten, Indonesia. In this year was the cause of conflict began to appear. Causes of conflict began to emerge when the Local Government (LG) Pandeglang permit the location and ground water exploitation permit to PT. FresindoTirta Jaya to establish a drinking water factory Le-Minerale.

Although permission was granted by the Local Government (LG) Pandeglang, the source of water at the site of PT. Fresindo Jaya included as part of the administrative district of Serang. Region that are at least 8 springs for the District Baros (Serang Regency) there are four water named Cilarangan, Cilisungbunian, Cikondang, and Cikopo, and in the District Cadasari (Pandeglang), there are four other springs named Cinangka, Ciwarasta, KeduBedul, and Kadu Bu'ut.

Then four springs in Cadasari was backfilled by gradually dredge agricultural land and settlements that have been purchased by PT. Fresindo Jaya. The land purchase was done through the village. Residents initially did not know the plan to build a drinking factory within its own territory. When the land acquisition happened at the end of 2013 villagers were told that the land used for housing.

PT. TirtaFresindo Jaya had asked permission since August 2013 and then in December the company received an approval letter from the government to build a (site plan) factory. Then at the same time, the activity of dredging settlement lands and paddy former residents who have been bought by the PT. TirtaFresindo Jaya also started. On March 5th, 2014, the 
Pandeglang Regent H. ErwanKurtubi gave permission to one Director of the Company Mayora Group to build the bottled water industry (Le-Minerale).

The information that the company that will operate the water utility company was hidden by using the village apparatus as a land broker by saying to the people that purchase of land earmarked for housing. The presence of PT. TirtaFresindo Jaya alleged to have violated the rules of the Regulation (Regulation) 3/2011 About Spatial Plan (RTRW) Pandeglang Year 2011-2031. The same regulation stated that the sub-district where the factory site cadasari including the water catchment areas (Article 31, paragraphs 1 and 2) geological protected areas (article 35 paragraph 4) and regional sustainable food agricultural land (Article 39, paragraph 6).

Yet further, the presence of companies that control water resources, ignoring the aspect of local wisdom. In the completion of the project suggestions PT. FresindoTirta Jaya in Serang and Pandeglang district, Forum Board Member of the National Water Resources, NonGovernment Element stated that the first point of the negative impact of the presence of the PT project. PT. FresindoTirta Jaya is resulting in loss of 7 springs, sacred tombs and historical sites. The other two were: lack of water sources for public consumption, as well as 100 hectares of drought and water shortages to Tangerang.

The religious-based community created the social movements against PT. TirtaFresindo Jaya. This was not surprising because in some locations there were 42 traditional pesantren (salafi). In addition, the position of the project was in the KramatMusola (Kaduawi) village, Cadasari district, Pandeglang.

In 2014 the movement began and organized by some Kyais as the pioneers. The Momentum was when on June 12, 2014 the Cadasri citizens held istighosah (praying together) at Honje Restaurant and agree to reject the project of PT TirtaFresindo Jaya. Furthermore, throughout the month of June to August, the community is led by some Kyais such as KH. UbingSurohman, KH Muslim, KH. Nahrowi, KH Bai Didi, KH Ahmad Khusaeri, KH. Izzudin, KH Sonhaji. Along with local figures and Santris, they held various meetings with local government officials, the polices and the other various parties to express rejection of the project by PT TirtaFresindo Jaya. Even at 17 September 2014 they held a peaceful protest at the Pandeglang Regency Office with thousands mass.

However, in 2015, the project kept continue. The representative of PT. TirtaFresindo Jaya through the village government apparatus trying to approach the Kyai. They came to AbuyaMuhtadi and said that the project will be continued. Furthermore, they also held various meetings to socialize the plan to the citizens, facilitated.by the village government.

Once again, people are getting restless. In a meeting attended by 118 Kyais, community leaders, military and police officers at boarding RiyadulWildanCadasari in Kampung Curug, they still expressed opposition to the project. They then declare the denial letter signed by KH. Husaeri Ahmad, chairman of Majelis Ulama Indonesia (Islamic Scholars Association) Cadasari and AbuyaMuhtadi as Banten Ulama leaders and submitted to the Regent Pandeglang. In addition to MUI, Jam iyatul Muslims Organization also submitted a complaint against the project PT. TirtaFresindo Jaya, addressed to the Banten Police. Then, they organized a peace rally attented by thousands of people and made audience with the Banten Province local parliament on 11 November 2015. The local parliament agree to stop the project of PT. TirtaFresindo Jaya[14].

However, the turmoil intensified until 2016. The of PT. TirtaFresindo Jaya continue to start the project work, that was considered to provoke the public. Refer to a letter from Ombudsman, PT.TirtaFresindo Jaya even involve military officer from Special Forces Command Group 1 (Kopassus) Serang to intimidate people and prevent rejection. 
Even though repeated clashes can be prevented, finally it was happened. On January 13, 2016 in the location of fencing project,pof the company, angry people gathered at the site to prevent fencing, resulting in the collapse of the fence project PT. TirtaFresindo Jaya along 50 meters.

After the incident, the police move quickly and asked the official of PT. TirtaFresindo Jaya to make report to the police. This attitude would increase anger and consolidation in the society. On January 28, 2016, the Muslim community made big meeting, praying together (istighosah) in Mosque of Kyai Cangkudu initiated by $\mathrm{KH}$ Nahrowi, head of PondokPesantrenRiyadulAwamil. The next day, residents gathered in the village of Kadu Awi, and in every village also implemented Istighosah. Citizens fear then proved when 10 residents consisting of Kyai, community leaders and youth, including KH Nahrowi then summoned by the Banten Police for questioning on February 5, 2016 [14].

But the turmoil resumed again in early 2017. On February 6, 2017 hundreds of people came to the Pandeglang regent's office stated their refusal to PT. TirtaFresindo Jaya. Disappointed that they cannot meet The Regent, the people then move to the location of the project. At the site, riots happen. Residents broke down the door of PT. Fresindo Jaya while throwing stones / bottles and Molotov into the company so that the combustion of heavy equipment and damaged buildings in the project. A day later, three residents were arrested.

Impact of the amok, the Acting Governor of Banten Nata Irawan through Banten Governor Decree No. 050/700-BAPP / 2017 states that the business permit of PT. TirtaFresindoJaya was expired. Long time fought between PT. TirtaFresindo Jaya and the Cadasari people led by Kiai from 2013 to 2017 showed that the Kiais in Banten Pandeglang- Cadasari are charismatic figures who had a great influence. Kyai leadership able to mobilize citizens not only faced with the corporation, but also local governments, even the security apparatus.This is interesting because in some studies about the social and political role of Kyai, there are several studies that positioned Kyai as political brokers, especially in the event of some sort of electoral politics[14], [15].

Leadership of Kyai to organize social movements against control of water resources by the corporation showed that Kyai in the community still has an important role as actors of social change. they did change by their social creativity.

Kyais not only dampen a result of social change, but pioneered and led social change itself. They not only as source of information, but rather to offer an agenda that considers changes in accordance with the needs of society they leads.

Real threat that threatens the livelihood of citizens agriculture while also disrupt water consumption for Pesantrens around the project PT. TirtaFresindo Jaya got a response in the form of an agenda of resistance against PT. TirtaFresindo Jaya. A wide variety of resistance efforts carried out by the religious leader as actor, and religious institutions (read: pesantren) as the basis.

Key figures in the rejection are the Kyaiz, both as a symbol like AbuyaMuhtadi, as well some Kyais who directly organizing in the field. Various consolidation meeting also largely conducted at the Pesantren. The method implemented, in addition to common methods such as demonstrations or hearings also praying together (istighosah). Religion gives energy and legitimacy to the resistance of citizens to PT. TirtaFresindo Jaya.

In the context of environmental social movement based on religion in Banten can be categorized as mobilizers. Corporate actions PT. TirtaFresindo Jaya that seeks control of water resources are considered as real threats to the environment for the surrounding community. Social movements built as an action against businesses that tried to control natural resources, in this case the water source. The source of water is the basic needs of society and the 
corporate domination would eliminate public access to the water source and the source of their life as a farmer. Agricultural environment that rely on water sources endangered. Resistance was also submitted to the government as a regulator that gives permission for the corporate business activities.

\section{Conclusion}

In the case of resistance to the projects of PT. TirtaFresindo Jaya in Cadasari, Pandeglang, Kyai become a main actor in mobilizing people in the resistance. Pesantren is not only a place studied religion but became a consolidated basis to take the fight with the various actions that has religious nuance. Kyai as charismatic leadership was able to defeat a legal- rational leadership such as local government and security forces. Both of them were considered to facilitate business actions detrimental to society.In this case Kyai role as actors of social change, which not only offers an agenda, but to lead the change agenda. Mobilizer social movements is at least capable of fighting and stopping business activity considered damaging to the environment and harmful to society.

\section{References}

[1] C. Tilly and Tarrow, Contentious Politics. Boulder: Paradigm Publisher, 2007.

[2] N. Martono, Sosiologi Perubahan Sosial. Jakarta: Rajawali Pers, 2011.

[3] E. Laclau and C. Mouffe, Hegemony and Socialist Strategy: Towards a Radical Democratic Politics. New York \& London: Verso, 2001.

[4] Suharko, "Model-model gerakan NGO Lingkungan, Studi Kasus di Yogyakarta," JSP, vol. 2, no. 1, 1998.

[5] H. V. . Heijden, "Environmental movements, ecological modernisation and political opportunity structures," Env. Polit., vol. 8, no. 1, pp. 199-221, 1999.

[6] M. Budiardjo, Dasar-dasar Ilmu Politik, Revisi. Jakarta: Gramedia Pustaka Utama, 2008.

[7] S. Kartodirdjo, Pemberontakan Petani Banten 1888. Jakarta: Pustaka Jaya, 1984.

[8] E. Turmudi, Perselingkuhan Kiai dan Kekuasaan. Yogyakarta: LKIS, 2003.

[9] H. Hiroko, Kiai dan Perubahan Sosial. Jakarta: LP3ES, 1987.

[10] Burhanuddin, "Ulama Sebagai Cultural Broker, Atau Pialang Politik?," Media Indonesia, 2000.

[11] Kuntowijoyo, "Muslim Tanpa Mesjid. Bandung: Mizan, 2001.

[12] M. Dimyati, Manakib Abuya Cidahu, Dalam Pesona Langkah Di Dua Alam [Biography of Abuya Cidahu, and his Ability to Live in Two Worlds]. Pandeglang: Tidak diterbitkan, 2008.

[13] J. . Cresswell, Research Design: Qualitative, Quantitative, and Mixed Methods Approach. California: Sage Publications, 2003.

[14] I. Ahmad, Perlawanan Kyai di Banten, Epik Modern Pesantren Salafiyah. Depok: Pustaka Empat Lima, 2016.

[15] A. Hamid, "Kiai in Banten, Shifting Role in changing times," in Islam in Contention: Rethinking Islam and State in Indonesia, Kyoto: Center for Southeast Asian Studies, M. Okamoto, O. Atsushi, and A. Suaedy, Eds. Jakarta: Wahid, pp. 415-443. 